\title{
Makna Menjadi Guru Bimbingan Konseling (Studi Fenomenologi Terhadap Fresh Graduate)
}

\author{
Andi Wahyu Irawan ${ }^{1}$, Aswar $^{2}$ \\ Universitas Mulawarman ${ }^{1}$, Sekolah Tinggi Ilmu Islam dan Bahasa Arab \\ (STIBA) Makassar ${ }^{2}$ \\ Email: andiwahyuirawan@ fkip.unmul.ac.id ${ }^{1}$, aswar@stiba.ac.id ${ }^{2}$
}

\begin{abstract}
:
Many new professions have sprung up with income that cannot be underestimated. This study aims to find the meaning of work to be a guidance and counseling teacher. This research uses a qualitative method of phenomenological approach. The subjects of this study were 4 (four) people who were determined by purposive sampling. Data collected techniques were in-depth interviews and analyzed using Interpretative Phenomenological Analysis (IPA) techniques. The analysis technique sought to find meaning themes to become counseling guidance teachers. The results show three main themes, those are counseling guidance teachers interpreted as: 1) a soul calling, not profit oriented, realizing the future of students, and religious beliefs 2) to enjoy comfort, is a sense of comfort when students are helped, enjoy being parents for students, and to get life lessons and 3) as a part-time job is waiting to become civil servants and not easily laid off..
\end{abstract}

Keyword: fresh, graduate, work, guidance, teacher

Received February 25, 2020; Revised March 18, 2020; Accepted April 1, 2020

How to Cite: Irawan A. W., Aswar. (2020). Makna Menjadi Guru Bimbingan Konseling (Studi Fenomenologi Terhadap Fresh Graduate). JKI (Jurnal Konseling Indonesia), 5(2), 47-53.

\section{PENDAHULUAN}

Pekerjaan merupakan suatu aktivitas kehidupan yang dilakukan untuk mencapai kebutuhan. Manusia hidup untuk memenuhi kebutuhannya, sekaligus menyatakan eksistensinya. Jika seseorang bekerja karena terdorong oleh kondisi tersebut, berarti kerja merupakan bagian yang paling mendasar dari kehidupannya lantaran dilakukan hanya untuk memperoleh status sosial di masyarakat.

Studi kualitatif yang dilakukan oleh (Lisma \& Haryono, 2016) menyimpulkan bahwa kebutuhan biologis merupakan kebutuhan tingkat pertama sebelum mencapai tingkat kebutuhan lainnya. Kebutuhan ini merujuk pada pemenuhan kebutuhan untuk bertahan hidup (makan dan melanjutkan keturunan). Manusia tidak akan bisa bertahan hidup tanpa makan. Untuk memenuhi kebutuhan tersebut, manusia berupaya untuk bertahan hidup dengan bekerja dan mendapatkan penghasilan untuk makan hingga mencapai tingkat kebutuhan lainnya.

Tempat kerja modern terus berubah dan profesi baru bermunculan hingga membentuk persepsi dan cara pandang manusia dalam memaknai pekerjaan. Menjadi youtuber atau conten creator misalnya, tidak harus terikat pada aturan yang kaku, datang pagi pulang sore. Atau menjadi guru di pedalaman desa, tidak mesti mendapatkan gaji yang melimpah karena kebaikan dan keramahan orang desa sudah bisa membayar segalanya. Profesi baru bermunculan dengan pendapatan yang tidak bisa dianggap remeh. Perubahan terhadap orientasi karir tersebut, 
telah membuka peluang lapangan pekerjaan di berbagai sektor, termasuk yang paling potensial adalah industri kreatif.

Profesi baru yang bermunculan tidak lantas membuat sebagian besar generasi 'milineals' mengikuti trend tersebut. Beberapa diantaranya masih menginginkan profesi yang sudah lama diidam-idamkan generasi sebelumnya, menjadi ASN misalnya. Menjadi ASN (Aparatur Sipil Negara) saat ini dan atau di era millenial tidak mudah. Mesti melalui seleksi yang ketat dan bersaing dengan peserta yang lain. Dulu bahkan mereka melalui tahap pertama yakni menjadi honorer. Padahal, dari segi pendapatan, menjadi honorer kurang menjanjikan kesejahteraan, utamanya kesejahteraan secara finansial.

Tenaga pendidik atau guru tidak lepas dari menjamurnya anak muda yang ingin menjadi ASN guru. Tidak sedikit yang memilih mengabdi menjadi tenaga honorer terlebih dahulu. Fenomena ini tentu terbilang menuai ketimpangan, karena aturan baru pemerintah mengharuskan seluruh tenaga honorer untuk tes CAT (Computer Assisted Test) layaknya formasi umum. Hal ini tentu menjadi pertanyaan, mengapa mereka ingin menjadi tenaga honorer padahal dari sisi pendapatannya cukup rendah. Jika mereka mau, masih banyak pekerjaan lain yang bisa dilakukan, semisal bekerja diperusahaan swasta dan atau berwirausaha.

Aktivitas kerja yang dilakukan akan membentuk pengalaman. Pengalaman kerja membentuk makna kerja pada setiap individu (Niessen, Weseler, \& Kostova, 2016). (Lee \& Hanna, 2015) menambahkan bahwa makna kerja tidak hanya sebagai upaya memenuhi kebutuhan dasar dari segi ekonomi, tetapi kebutuhan sosial dan aktualisasi diri. Penelitian terkait mengenai pekerjaan telah dilakukan oleh Max Weber dengan menghubungkan agama terhadap etika dan etos kerja. Weber menulis buku dengan judul The Protestant Ethic and the Spirit of Capitalism (Nielsen, 2016). Dalam bukunya, Weber meyakini bahwa agama protestan di Eropa Barat telah berperan besar dalam mendorong kebutuhan berprestasi ummat manusia, hingga akhirnya memunculkan paham kapitalisme. Etika kerja tersebut disebut sebagai etika protestan yang di ajarkan oleh John Calvin. Ajaran Calvin menganjurkan agar setiap manusia melakukan sesuatu yang terbaik dan berusaha agar bisa berprestasi. Ajaran tersebut berimplikasi terhadap sikap kerja keras para penganutnya. Menurut Weber, tujuan mereka bekerja keras hanya untuk mencari kekayaan, dan juga untuk mempersiapkan diri agar bisa masuk surga. Pada intinya, etika protestan mengajarkan penganutnya untuk bekerja keras dan bersungguh-sungguh tanpa berorientasi mendapatkan imbalan materil (Nadjib, 2013).

Penelitian yang dilakukan oleh (Puspita, 2012) mengenai makna dalam bekerja, dengan mengambil sampel dari para perawat rumah sakit swasta di kota Surabaya, menyimpulkan bahwa para perawat memaknai pekerjaannya sebagai bagian dari panggilan jiwa karena rekan kerja memberikan dukungan sosial sehingga dalam bekerja, mereka merasa tidak terbebani dan memiliki semangat dalam bekerja. Penelitian dengan topik serupa dilakukan oleh (Rusdiana \& Affandi, 2013). Mereka meneliti mengenai makna kerja bagi buruh petik lombok di Pare. Penelitian tersebut menyimpulkan bahwa para petani memaknai pekerjaannya sebagai bagian dari pengisi waktu luang, menambah penghasilan keluarga, sebagai adaptif dengan lingkungan sosial, keterpaksaan, sumber penghasilan utama demi kelangsungan keluarga, usaha mengumpulkan modal, upaya penunjukkan eksistensi diri. Penelitian lain yang dilakukan oleh (Anshori \& Yuwono, 2013) tentang makna kerja "abdi dalem" keraton Yogyakarta, menyimpulkan bahwa 1) Bekerja merupakan kegiatan yang bertujuan mencari ketenangan, ketentraman dan kebahagiaan, 2) Bekerja dengan prinsip nyawiji, greget, sengguh, lan ora mingkuh, 3) Nguri-uri kabudayan, 4) Prinsip sugih tanpa banda, 5) Ngalap berkah, 6) Bekerja dengan pemahaman sangkan paraning dumadi, 7) golong gilig, manunggaling kawula lan gusti, 8) Bekerja merupakan suatu kegiatan untuk srawung dan ngluru prepat, 9) Hamemayu hayuning Bawana, hamemangun karinak tiyasing sesama, 10) Bekerja dengan penuh mawas diri.

Tiga penelitian diatas menunjukkan beberapa perbedaan dalam memaknai pekerjaan. Perawat yang bekerja di rumah sakit, berbeda dalam memaknai pekerjaan jika dibandingkan dengan petani lombok dan "abdi dalem" di keratin Yogyakarta. Hal ini menunjukkan bahwa setiap orang memiliki pandangan dan persepsi masing-masing terhadap pekerjaannya, tergantung dengan pengalaman yang mereka miliki.

Makna pekerjaan sebagai guru diteliti oleh (Tanudjaja, 2013) melalui studi kuantitatif. Penelitiannya mengkaji mengenai hubungan antara konflik keluarga-kerja, makna kerja sebagai panggilan dan persepsi terhadap dukungan organisasional dengan keterikatan kerja pada guru. Penelitian tersebut menyimpulkan bahwa konflik keluarga-kerja berperan sebagai tuntutan kerja yang memunculkan stressor bagi guru, namun ada persepsi terhadap dukungan organisasional dan makna kerja sebagai panggilan yang mengurangi stressor dan meningkatkan keterikatan kerja. Hal ini menunjukkan bahwa meskipun terjadi konflik di keluarga maupun di pekerjaan, tetapi guru berusaha menguragi stressnya dengan mendapatkan dukungan dari teman sejawat maupun memaknai pekerjaannya sebagai suatu panggilan jiwa.

Makna kerja merupakan sekumpulan nilai-nilai, keyakinan-keyakinan, sikap dan harapan yang dimiliki seseorang dalam hubungan dengan kerja. Pemaknaan akan arti kerja bagi seseorang akan berdampak pada semangat kerja orang tersebut. Semangat kerja dibentuk dari dasar pemahaman dan spiritual individu, yang pada 
akhirnya akan memberikan dorongan motivasi yang kuat dalam dirinya untuk bekerja dengan maksimal (Guillén, Ferrero, \& Hoffman, 2015).

Fenomena yang terjadi di kota Samarinda adalah kurang terserapnya alumni bimbingan konseling di sekolah. Salah satu perguruan tinggi negeri di samarinda yang memproduksi dan menyuplai guru bimbingan dan konseling, setiap tahunnya menerima 80 (delapan puluh) mahasiswa baru. Namun, kenyataannya hanya sedikit alumni yang bekerja sebagai guru bimbingan konseling. Mahasiswa angkatan 2012 saja, dari delapan puluh alumni, hanya 2 (dua) orang yang menjadi guru bimbingan konseling. Lantas, apa yang menyebabkan sebagian kecil alumni bimbingan konseling memilih jalan karir untuk menjadi guru dan bagaimana mereka memaknai pekerjaannya sebagai guru bimbingan konseling. Penelitian ini akan menelusuri pemaknaan kerja guru bimbingan konseling di kota Samarinda.

\section{METODE PENELITIAN}

Penelitian ini menggunakan metode kualitatif pendekatan fenomenologis untuk mengetahui makna menjadi guru bimbingan konseling bagi fresh graduate di kota Samarinda. Pendekatan fenomenologis merupakan upaya peneliti secara metodologis untuk membuat gambaran kompleks, mendalami kata-kata, melakukan studi pada situasi yang alami, dan membuat laporan rinci dari pandangan subyek (Levitt, Motulsky, Wertz, Morrow, \& Ponterotto, 2017). Pada intinya, pendekatan fenomenologis digunakan untuk mengetahui pemaknaan individu terhadap pengalamannya sendiri.

Subjek penelitian ini berjumlah 4 (empat) orang yang ditentukan dengan cara purposive sampling. Kriteria subjek penelitian adalah guru bimbingan konseling yang tergolong fresh graduate dan mengabdi tidak lebih dari satu tahun, berstatus sebagai honorer, berusia tidak lebih dari 25 tahun, dan bekerja di salah satu sekolah negeri di Kota Samarinda. Para partisipan tersebut disamarkan namanya, yaitu subjek A, B, C, dan D. Empat orang subjek penelitian tersebut akan menjadi data primer atau data utama dalam penelitian ini. Adapun data sekunder yaitu perwakilan setiap siswa yang pernah dilayani oleh guru bimbingan konseling tersebut dan dokumen terkait yang bisa menguatkan data penelitian.

Teknik pengumpulan data yang digunakan adalah wawancara mendalam dan observasi. Wawancara diatur sedemikian rupa agar berjalan secara natural dan apa adanya. Peneliti membangun hubungan emosional yang kuat agar data yang didapatkan bisa mendalam. Secara garis besar pertanyaan wawancara berkisar tentang alasan menjadi guru bimbingan dan konseling, apa makna menjadi guru bimbingan dan konseling, apa yang membuat mereka bertahan menjadi guru bimbingan dan konseling, dan bagaimana pandangannya tentang profesi lainnya yang lebih menggiurkan. Wawancara dilakukan selama 3 (tiga) kali kepada setiap subjek penelitian untuk menguji konsistensi data yang diungkapkan.

Observasi dilakukan oleh peneliti untuk mengamati sikap dan perilaku yang dilakukan oleh subjek penelitian. Observasi dilakukan ketika peneliti berkunjung dan berbincang langsung dengan guru bimbingan konseling, serta melihat dan mengamati secara langsung kinerja yang dilakukan oleh guru bimbingan konseling. Data-data dari observasi dibandingkan dengan wawancara untuk menguji kesesuaian diantara keduanya.

Analisis data menggunakan interpretative phenomenological analysis (IPA) dengan langkah-langkah dari Smith \& Osborn (2009), yaitu: mentranskrip seluruh data hasil wawancara menjadi verbatim, peneliti melakukan pengkodean dengan cara memberikan komentar pada masing-masing transkrip, komentar-komentar pada transkrip dibaca ulang untuk membuat label konseptual, kemudian label dikelompokkan berdasarkan kesamaan makna dan diberikan nama subtema. Subtema kemudian dianalisis untuk dikelompokkan berdasarkan kedekatan makna dan diberikan nama tema utama. Proses analisis data hingga menemukan tema-tema merupakan upaya untuk sampai pada kesimpulan penelitian. Beberapa data asli (ekstrak) ditulis dalam laporan penelitian untuk menjaga transparansi penelitian. Ekstraksi data tersebut disebut sebagai grounding in example (Levitt et al., 2017).

\section{HASIL}

Penelitian ini bertujuan untuk menemukan makna kerja menjadi guru bimbingan dan konseling. Data-data yang didapatkan pada saat wawancara dan observasi, dikategorikan berdasarkan tema utama sesuai dengan tujuan penelitian. Tema utama dikategorikan menjadi tiga, yaitu menjadi guru sebagai panggilan jiwa, menikmati kenyamanan, dan sebagai selingan. 
Panggilan Jiwa

Tidak Berorientasi Profit

"Sejauh ini ga pernah menyesal aku mengambil jurusan BK, justru dr jurusan ini aku dpt lebih mengenal diriku, meskipun gajinya tidak seberapa, cuman 1,1 juta."

Subjek A berpendapat bahwa meskipun gajinya tidak sesuai yang dia harapkan, tapi dengan mendapatkan pemahaman terhadap dirinya, ia sudah bisa bersyukur, apalagi dengan usianya yang masih sangat muda. Kemudian subjek B berpendapat;

"Kalau bicara profit mungkin saya sudah dari dulu cari tempat lain yang jauh lebih banyak gajinya mas. Ditempat saya gajinya mepet mas, mungkin cuma cukup untuk transport."

Subjek B membuat statement bahwa dirinya tetap konsisten untuk menjadi guru bimbingan konseling meskipun dengan gaji yang hany cukup untuk biaya transport. Baginya, rejeki itu sudah diatur oleh Allah, persoalan gaji itu cuman nominal saja.

Ketika subjek $\mathrm{C}$ ditanya mengenai kenapa tidak menjadi pegawai swasta saja karena gajinya lebih banyak, ia kemudian menjawab;

"Kenapa tidak jadi pegawai swasta. Bukan minat disitu mas. Minatnya didunia pendidikan. Mengamalkan ilmu. InsyaAllah walaupun belum bisa amal materi. Amal ilmu bisa manfaat hehe..."

Mewujudkan Masa Depan Siswa

"Bagi saya mewujudkan masa depan siswa adalah kerja yang luar biasa. Sampai saat ini saya masih sering komunikasi dengan siswa yang sudah selesai. Rasanya itu seperti bonus, rasa terpanggil untuk melakukan yang lebih baik untuk siswa semakin terpacu."

Subjek D beranggapan bahwa kerjanya menjadi guru bimbingan dan konseling merupakan upayanya untuk mewujudkan masa depan siswa. Menurutnya, ini merupakan panggilan jiwa yang luar biasa. Ia terus berusaha memacu dirinya untuk memberikan pelayanan yang lebih baik untuk siswa.

Keyakinan Agama

"Aku bekerja sebagai guru bimbingan konseling karena aku meyakini bahwa apa yang aku lakukan ini menjadi amal jariyah dikemudian hari. Semua yang kulakukan ini aku niatkan karena Allah. Aku jadikan ini sebagai amal ibadahku."

Subjek A beranggapan bahwa apa yang dilakukannya itu merupakan amal jariyah, setiap usaha yang dia lakukan diniatkan karena Allah. Statement tersebut merupakan keyakinan subjek E terhadap ajaran agamanya. Baginya, kerja menjadi guru bimbingan konseling merupakan panggilan jiwa.

Menikmati Kenyamanan

Rasa Nyaman Ketika Siswa Terbantu

“Karena ketemu anak-anak yang kondisinya 'begitu' jadi tersentuh mas hehe...

Butuh perhatian dan kasih sayang. Saya merasa nyaman aja kalo dekat dengan mereka."

Subjek B merasa bahwa makna menjadi guru bimbingan dan konseling bagi dirinya adalah menikmati kenyamanan ketika bisa membantu siswa. Subjek B nyaman karena bisa membantu siswa yang bermasalah. Baginya, rasa nyaman itu membuatnya menjadi guru bimbingan konseling.

Menikmati Menjadi Orang Tua Bagi Siswa

"Guru bimbingan konseling bukan sekedar jadi tempat konseling tapi bagaimana menjadi orang tua bagi mereka yang membutuhkan. Selama ini siswaku hampir sebagian besar dari keluarga 'broken home' dan kurang perhatian. Sistem bimbingan konseling di sekolahku yang akhirnya harus jadi ortu dalam arti sesungguhnya, ada yang jadi ayah dan aku jadi ibunya anak-anak. Itu menjadi sesuatu yang nyaman bagi saya."

Subjek C mencoba untuk menjelaskan kondisi sekolahnya dan kemudian menganggap bahwa dirinya merupakan ibu bagi siswa-siswa dalam arti yang sebenarnya. Karena banyak siswa yang kurang kasih sayang orang tua. Baginya, itu merupakan perlakuan yang membuat dia merasa nyaman.

Mendapat Pelajaran Hidup

"Dari siswa itu saya justru banyak belajar, banyak hal yang bisa saya pelajari dari pengalaman, Misalnya.. mengatakan 'tidak' kepada anak. Kita sering melakukan berkali-kali dan hampir semua orang menganggap lumrah ketika kita ingin menolak sikap anak dengan kata 'tidak'. Tapi nyatanya 1 kata itu apabila penempatannya tidak tepat dampaknya cukup besar untuk anak kedepannya."

Subjek D beranggapan bahwa menjadi guru bimbingan dan konseling merupakan upaya untuk belajar kembali. Dia justru belajar dari siswa-siswanya. Karena menurutnya, satu kata saja, atau respon yang jelek kepada siswa, maka akan berdampak pada siswa. Dari situ ia belajar untuk menggunakan kata yang sesuai pada penempatannya. Selingan

Menunggu jadi ASN

"Yang membuat saya bertahan sampai saat ini menjadi guru bimbingan konseling adalah, karena saya nunggu untuk pembukaan lowongan ASN lagi. Hehehe. Saya akan mencoba menjadi guru bimbingan dan konseling 
meskipun hanya menjadi tenaga honorer. Tapi tidak bisa terus menerus seperti ini. ketika saya sudah memiliki keluarga nanti, saya berusaha untuk mencari pekerjaan lain jika saya tidak menjadi ASN."

Pendapat subjek A tentang pekerjaannya rupayanya kontradiksi dengan pendapat sebelumnya. Disisi lain ia menganggap pekerjaan guru bimbingan dan konseling sebagai penggilan jiwa, tetapi disisi lain ia menjadikan pengabdiannya itu sebagai jalan untuk menjadi ASN. Jika nanti dia sudah berkeluarga dan keadaan memungkinkan, maka ia lebih memilih mencari pekerjaan lain.

Tidak mudah di PHK

"Banyak pengalaman teman saya itu yang kerja di perusahaan beberapa tahun, tapi ujung-ujungnya di PHK. Yah aku gak mau kayak gitu lah. Tidak menjanjikan contohnya PHK. Banyak lembur. Aku lihat jadi guru juga banyak liburnya. Hehe..."

Bagi subjek B, menjadi guru bimbingan konseling merupakan posisi aman. Dia tidak ingin bekerja di perusahaan swasta karena takut di PHK atau sampai bekerja lembur. Hal ini menunjukkan bahwa subjek B merasa bahwa menjadi guru bimbingan dan konseling merupakan profesi yang aman, jauh dari PHK ataupun bekerja lembur. Apalagi menurutnya, profesi guru itu banyak liburnya, kalau siswa libur, guru pun ikut libur, tergantung dari kondisi sekolah.

\section{PEMBAHASAN}

Hasil penelitian menunjukkan 3 (tiga) tema utama makna menjadi guru bimbingan konseling. Pertama, sebagai panggilan jiwa; kedua, menikmati kenyamanan; dan ketiga, sebagai batu loncatan. Dari ketiga tema tersebut, kemudian membentuk subtema. Subtema dari panggilan jiwa; tidak berorientasi profit, mewujudkan masa depan siswa, dan keyakinan agama. Subtema dari menikmati kenyamanan; rasa nyaman ketika siswa terbantu, menikmati menjadi orang tua bagi siswa, dan mendapat pelajaran hidup. Subtema batu loncatan; menunggu jadi ASN dan tidak muda di PHK.

Hasil penelitian menunjukkan bahwa ada beberapa bagian dari statement subjek penelitian yang saling kontradiktif, misalnya menjadikan pekerjaan guru bimbingan dan konseling sebagai panggilan jiwa tapi disisi lain subjek penelitian menganggap bahwa ia menjadi guru bimbingan dan konseling karena dianggap sebagai profesi yang aman jika dibandingkan dengan pekerjaan lain misalnya di swasta, dengan akibat terjadi PHK.

Penelitian yang dilakukan oleh (Pohling, Buruck, Jungbauer, \& Leiter, 2016) menyimpulkan bahwa peran pekerjaan menggambarkan banyak hal yang berkaitan dengan cara bekerja seseorang. Setiap dimensi dari peran pekerjaan mencakup aspek materi pekerjaan yang dapat mempengaruhi produktivitas kerja seseorang, semakin besarnya keragaman aktivitas pekerjaan yang dilakukan maka seseorang akan merasa pekerjaannya semakin berarti dan atau bermakna. Guru bimbingan konseling yang merasa bahwa pekerjaannya dinamis dan beragam, maka ia akan berusaha untuk meningkatkan produktivitasnya. Hal yang perlu diperhatikan tentu peran keberagaman bekerja dalam membentuk makna bekerja.

Pembentukan makna kerja juga dipengaruhi oleh ajaran agama, sebagaimana yang diungkapkan oleh Weber (Epley, 2015) menyoroti bahwa doktrin protestan berpengaruh terhadap etos kerja seorang Kristen. Doktrin tersebut menekankan bahwa kerja merupakan bagian dari ibadah dan panggilan untuk menata masyarakat. Makna kerja yang disebut oleh Weber merupakan panggilan suci dari tuhan. Sehingga menurut Weber, individu yang memiliki pemahaman agama yang kuat, akan berusaha untuk bekerja keras dalam menyelesaikan pekerjaannya.

(Guillén et al., 2015) menyatakan bahwa pekerjaan merupakan rencana Tuhan yang Maha Esa dari semula dan merupakan anugerah bagi manusia. Sebelum kejatuhan, manusia diberikan mandat untuk mengusahakan bumi. Hal ini merupakan perintah yang jelas dari Tuhan yang Maha Esa agar manusia bekerja untuk menghasilkan sesuatu. Pekerjaan apapun, harus dilakukan dengan kesungguhan, demi kemuliaan Tuhan yang Maha Esa. Oleh karena itu, setiap manusia yang bekerja, harus terus meningkatkan kompetensinya agar mampu bekerja secara professional, namun tetap dalam iman dan harapan yang teguh kepada Tuhan yang Maha Esa.

Makna kerja sebagai panggilan jiwa merupakan satu keterkaitan dengan ajaran agama. Hal ini tentu berlandaskan pada keyakinan seseorang. Keyakinan terhadap ajaran agama yang kuat, memberikan interpretasi pada individu mengenai maknanya dalam melakukan suatu pekerjaan.

(Jussila, Tarkiainen, Sarstedt, \& Hair, 2015) menyatakan tentang aspek pokok perilaku individu yaitu individu selalu bertindak sesuai dengan makna (yang dimiliki dan dialami), sehingga guru bimbingan dan konseling bekerja untuk menikmati kenyamanan yang mereka alami dari setiap layanan yang diberikan kepada konseli. Pemaknaan tersebut ada karena mereka melakukan interaksi dalam pekerjaan mereka. Mereka harus mengimplimentasikan makna tersebut dengan cara tetap bekerja sebagai guru bimbingan dan konseling yang dirasa memberikan kenyamanan dalam dirinya. Hal ini menunjukkan fakta bahwa data penelitian yang mengkategorisasikan makna kerja menjadi subtema rasa nyaman ketika membantu siswa, menikmati menjadi orang tua bagi siswa, dan mendapatkan pelajaran hidup, merupakan bukti bahwa guru bimbingan dan konseling 
melakukan interaksi dalam pemberian layanannya. Interaksi tersebut membentuk makna kerja yang diyakini oleh konselor.

Temuan penelitian selanjutnya adalah tema selingan, dengan subtema menunggu jadi ASN dan tidak mudah di PHK. Subjek penelitian menganggap bahwa profesi guru bimbingan dan konseling sebagai tenaga honorer, merupakan jalan cepat menuju ASN. Mereka berpendapat bahwa menjadi tenaga honorer, merupakan selingan untuk menunggu menjadi ASN. Selain itu, subjek penelitian juga menganggap bahwa menjadi guru bimbingan dan konseling merupakan posisi yang aman dibandingkan jika mereka bekerja sebagai karyawan swasta. Hal ini sejalan dengan pendapat (Chai, Bradley, Lo, \& Reser, 2015) bahwa waktu luang erat kaitannya dengan waktu apabila masuk dalam kategori discretionary time, yakni waktu yang digunakan menurut penilaian dan pilihan kita sendiri.

\section{SIMPULAN DAN SARAN}

Pekerjaan merupakan bagian dari upaya untuk memenuhi kebutuhan, sekaligus sebagai penemuan makna kehidupan. Makna kerja setiap individu berbeda-beda, tergantung dari keyakinan dan kondisi dilingkungan kerjanya. Namun tidak bisa dipungkiri bahwa dalam satu profesi, individu membangun persepsi atas kebermaknaan pekerjaannya secara general. Jika kondisi lingkungan kerja nyaman, maka individu akan membangun makna kerja yang positif.

Pekerjaan sebagai guru bimbingan dan konseling memang tidak mudah. Pekerjaan yang melibatkan interaksi antar konseli ini menuntut keterampilan interpersonal konselor yang matang. Hasil penelitian menunjukkan bahwa guru bimbingan dan konseling memaknai pekerjaannya sebagai panggilan jiwa, menikmati kenyamanan, dan sebagai selingan. Tema pangggilan jiwa berupa guru bimbingan konseling yang tidak berorientasi profit, merupakan pekerjaan yang mulia karena berusaha untuk mewujudkan masa depan siswa, dan sebagai bagian dari keyakinan agama yang mereka pahami. Selanjutnya, guru bimbingan dan konseling memaknai pekerjaannya untuk menikmati kenyamanan dengan subtema merasa nyaman ketika membantu siswa, menikmati menjadi orang tua bagi siswa, dan mereka mendapatkan pelajaran hidup dari upaya bantuan yang dilakukan. Pemaknaan selanjutnya adalah sebagai selingan, dikarenakan mereka bekerja sebagai tenaga honorer yang merupakan batu loncatan untuk masa penantian menjadi ASN (Aparatur Sipil Negara), sekaligus membuat kondisi mereka menjadi aman karena ketakutannya di PHK jika bekerja sebagai karyawan di perusahaan swasta.

Saran dari penelitian ini diharapkan menjadi rujukan dalam membantu guru bimbingan konseling dalam proses pemaknaan pekerjaannya melalui pengondisian lingkungan yang positif untuk meningkatkan produktivitas mereka dalam bekerja.

\section{DAFTAR RUJUKAN}

Anshori, N. S., \& Yuwono, C. D. I. (2013). Makna Kerja (Meaning of Work) Suatu Studi Etnografi Abdi Dalem Keraton Ngayogyakarta Hadiningrat Daerah Istimewa Yogyakarta. Jurnal Psikologi Industri Dan Organisasi, 2(3), 157.

Chai, A., Bradley, G., Lo, A., \& Reser, J. (2015). What time to adapt? The role of discretionary time in sustaining the climate change value-action gap. Ecological Economics, 116, 95-107.

Epley, J. L. (2015). Weber's theory of charismatic leadership: The case of muslim leaders in contemporary Indonesian politics. International Journal of Humanities and Social Science, 5(7), 7-17.

Guillén, M., Ferrero, I., \& Hoffman, W. M. (2015). The neglected ethical and spiritual motivations in the workplace. Journal of Business Ethics, 128(4), 803-816.

Jussila, I., Tarkiainen, A., Sarstedt, M., \& Hair, J. F. (2015). Individual psychological ownership: Concepts, evidence, and implications for research in marketing. Journal of Marketing Theory and Practice, 23(2), 121-139.

Lee, J. M., \& Hanna, S. D. (2015). Savings goals and saving behavior from a perspective of Maslow's hierarchy of needs. Journal of Financial Counseling and Planning, 26(2), 129-147.

Levitt, H. M., Motulsky, S. L., Wertz, F. J., Morrow, S. L., \& Ponterotto, J. G. (2017). Recommendations for designing and reviewing qualitative research in psychology: Promoting methodological integrity. Qualitative Psychology, 4(1), 2.

Lisma, N., \& Haryono, A. (2016). Analisis perilaku konsumsi mahasiswa ditinjau dari motif bertransaksi (Studi kasus pada mahasiswi S1 Pendidikan Ekonomi Fakultas Ekonomi Universitas Negeri Malang angkatan tahun 2012). Jurnal Pendidikan Ekonomi (Economic Education Journal), 9(1).

Nadjib, M. (2013). Agama, Etika dan Etos Kerja dalam Aktivitas Ekonomi Masyarakat Nelayan Jawa. Jurnal 
Ekonomi Dan Pembangunan, 21(2), 137-150.

Nielsen, D. A. (2016). The Protestant Ethic and the "Spirit" of Capitalism as Grand Narrative. The Protestant Ethic Turns 100: Essays on the Centenary of the Weber Thesis, 53.

Niessen, C., Weseler, D., \& Kostova, P. (2016). When and why do individuals craft their jobs? The role of individual motivation and work characteristics for job crafting. Human Relations, 69(6), 1287-1313.

Pohling, R., Buruck, G., Jungbauer, K.-L., \& Leiter, M. P. (2016). Work-related factors of presenteeism: The mediating role of mental and physical health. Journal of Occupational Health Psychology, 21(2), 220.

Puspita, M. D. (2012). Hubungan antara dukungan sosial dan makna kerja sebagai panggilan (calling) dengan keterikatan kerja. Calyptra, 1(1), 1-17.

Rusdiana, O., \& Affandi, M. A. (2013). Makna Kerja Bagi Buruh Petik Lombok di Pare. Paradigma, 1(3), 1-5.

Tanudjaja, R. M. (2013). Hubungan antara konflik keluarga-kerja, makna kerja sebagai panggilan, dan persepsi terhadap dukungan organisasional dengan keterikatan kerja pada guru. Calyptra, 2(1), 1-10. 